\title{
Underexpanded covered-stent
}

\author{
Tam açılmayan kaplı stent \\ Doğu İsmail Kıııc, Yusuf İzzettin Alihanoğlu, Bekir Serhat Yıldız, Harun Evrengül
}

Pamukkale Üniversitesi, Tıp Fakültesi Kardiyoloji AD, Denizli

\begin{abstract}
Coronary perforations are feared and potentially lethal complications in the cardiac laboratory. Therapeutic strategies include prolonged balloon inflation, reversal of anticoagulation, embolization of the distal vessel and surgery. Deployment of a covered stent is another therapeutic approach especially when the tear is large and involves proximal or mid coronary artery. Due to the high profile and poor flexibility of polytetrafluoroethylene (PTFE) covered stents; it is often difficult to deliver them to the target site, especially when the vessel is heavily calcified and tortuous. Although they can usually effectively seal the perforations, full expansion should be ensured as any other stent. However, in the chaotic milieu of these life-threatening complications, it can be overlooked. This case is a reminder of the importance of optimal expansion of the covered-stents.
\end{abstract}

Pam Med J 2014;7(2):246-249

Key words: Covered stent, Coronary perforation, Underexpansion.

\section{Özet}

Koroner perforasyonlar kardiyoloji kateter laboratuarlarında korkulan ve potansiyel olarak ölümcül olabilen komplikasyonlardır. Uzun süreli balon şişirilmesi, antikoagulan tedavinin etkisinin ortadan kaldırılması, distal damarın embolizasyonu ve cerrahi tamir tedavi seçeneklerini oluşturmaktadır. Ayrıca, koroner arterin proksimal ve mid bölgesini tutan geniş yırtıklarda kaplı stent kullanılması bir diğer tedavi alternatifidir. Yoğun profil yapısı ve zayıf fleksibilitesi nedeniyle politetrafloroetilen (PTFE) kaplı stentlerin hedef damara yerleştirilmesi, özelliklede damar yapısı yoğun kalsifik ve tortüyöz olduğu durumlarda genellikle zordur. Bunlar genellikle koroner perforasyonları etkili şekilde kapatmalarına rağmen diğer tüm stentlerde olduğu gibi kaplı stentlerinde tam olarak açıldığından emin olunmalıdır. Bununla beraber, hayati tehlike taşıyan bu komplikasyonun yarattığı kaotik ortamda bu detay gözden kaçırılabilmektedir. Kaplı stentlerin optimal açılmasının klinik önemine işaret etmesi açısından bu vaka takdimini sunuyoruz.

Pam Tip Derg 2014;7(2):246-249

Anahtar sözcükler: Kaplı stent, koroner perforasyon, Stentin tam açılmaması.

\section{Introduction}

Coronary artery perforations (CAPs) are rare but feared complications of percutaneous coronary interventions. Incidence changes with several patients, lesion and procedure characteristics, and studies have reported an incidence ranging from 0.29 to 3.0 [1]. Risk increases with the complexity of the lesions including chronic total occlusions, angulated calcified lesions, long (>10 mm), eccentric lesions and small vessel size [2]. Therapeutic strategies include prolonged balloon inflation, reversal of anticoagulation, embolization of the distal vessel and surgery [3]. We here present a case indicating the importance of optimal expansion of the covered-stents to completely treat coronary artery perforation.

\section{Case Report}

A 64 year-old male patient previously known as having hypertension for 15 years, diabetes mellitus for 5 years and coronary artery disease referred for cardiac catheterization due to his exertional angina. Additionally, it has been understood from his medical history that a percutaenous coronary intervention was performed 10 years ago because of an acute coronary syndrome. On his physical examination, blood pressure was detected as being $130 / 80 \mathrm{mmHg}$, and the heart rate as

Yusuf İzzettin Alihanoğlu

Yazışma Adresi: Pamukkale Üniversitesi, Tıp Fakültesi Kardiyoloji AD, Denizli

e-mail: aliizyu@mynet.com 
85/min. Except an apical $3 / 6$ systolic ejection murmur, no pathological sound was heard during pulmonary and cardiac auscultation. Routine biochemical and hemogram measurements of the patient were in the normal ranges. Her ejection fraction was assessed as $50 \%$, mild mitral and tricuspid valve regurgitations were detected in transthoracic echocardiography. Electrocardiography was at the normal sinus rhythm and demonstrated a precordial V1-4 QS pattern indicating an old anterior myocardial infarction.

On coronary angiography, while there were noncritical atherosclerotic plaques in right coronary artery and circumflex coronary artery, a significant in-stent restenosis in the left anterior descending coronary artery was shown (Figure A). The lesion was easily crossed with a floppy guidewire and dilated with a $3.0 \times 15$ compliant balloon at 15 atmospheres. During inflation balloon was not completely expanded. Moreover, contrast injection revealed marked extravasation (Ellis classification type 3) (Figure B). Since prolonged balloon inflation and reversal of anticoagulation did not seal the perforation, a covered- stent (JOSTENT GraftMaster [Abbot Vascular Inc.] $3.0 \times 19 \mathrm{~mm}$ at $14 \mathrm{atms}$ ) advanced to the area and inflated to 12 atms for 15 seconds. Despite the covered stent, extravasation continued and underexpansion of the covered stent was noticed which was possibly due to previous unexpanded resistant lesion (Figure C,D). Making things worse, balloon of the covered-stent could not be advanced back into the stent. Therefore, another $3.5^{\star} 24 \mathrm{~mm}$ balloon was advanced to fully expand the stent. Final angiography revealed no extravasation (Figure E). The patient was hemodinamically stable during the procedure. On emergent echocardiographic evaluation, no pericardial effusion or tamponade signs were detected.
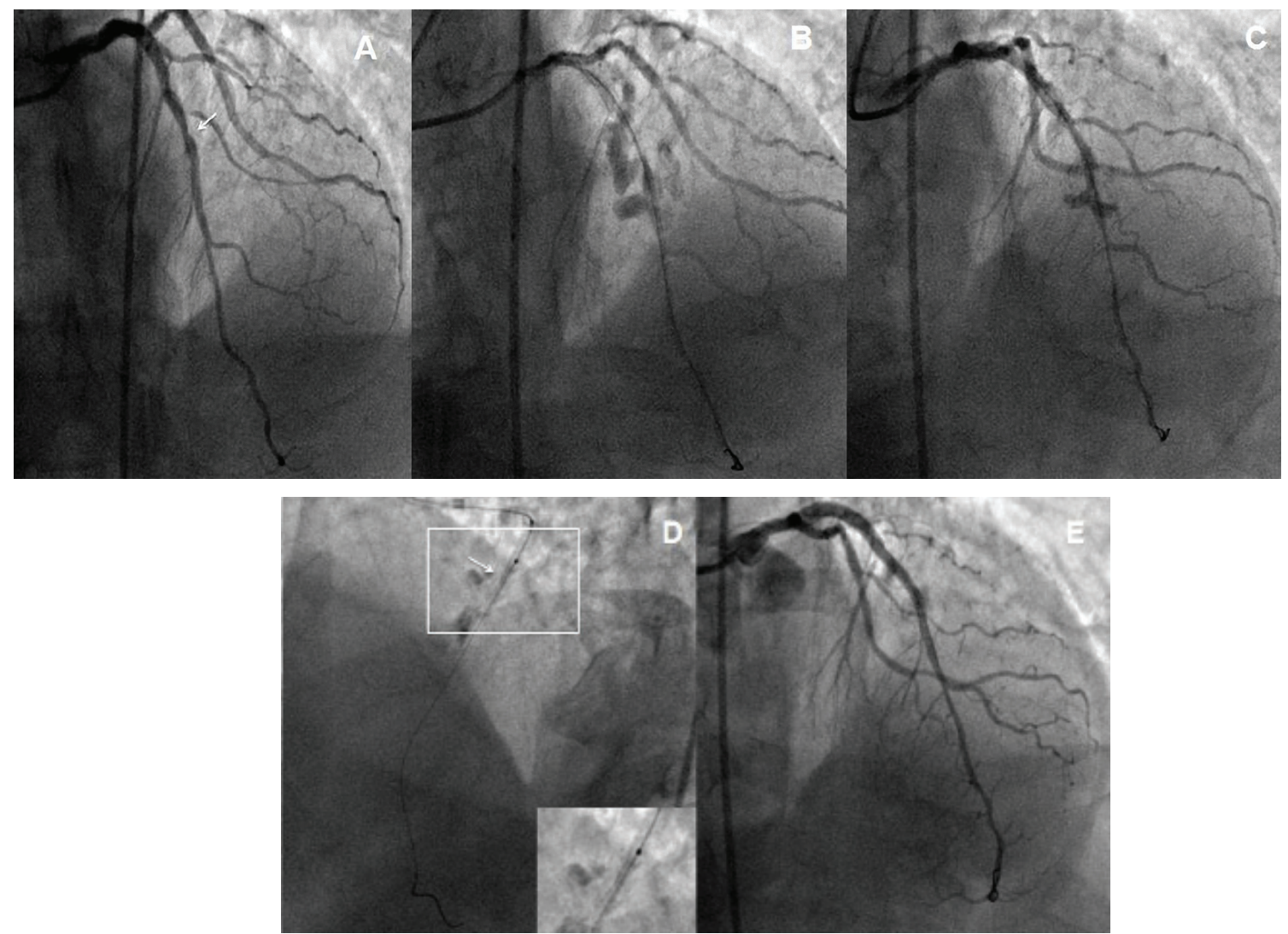

Figure 1. A: Arrow shows instent restenosis B: Coronary perforation Ellis type 3 C: Coronary leak continues after graft stent deployment $\mathbf{D}$ : Unexpanded graft stent $\mathbf{E}$ : After postdilatation, graft stent completely seals the perforation.

\section{Discussion}

Coronary artery perforations are rare but feared complications of percutaneous coronary interventions $(\mathrm{PCl})$. Incidence changes with several patient, lesion and procedure characteristics and studies have reported an incidence ranging from 0.29 to 3.0 [1]. Risk increases with the complexity of the lesions including chronic total occlusions, angulated calcified, long lesions and with small vessel size [2]. Older age and previous coronary artery bypass graft surgery also increase the risk. Other risk factors include diabetes mellitus, hypertension, and chronic renal failure [4]. 
Ellis et al. classified coronary perforations based on their angiographic appearances [1]. Type 1 perforations are limited to the vessel wall and produce an intramural crater without extravasation on the angiogram. Type 2 and 3 are not limited to the vessel wall in contrast to type 1. Type 2 perforations show limited extravasation with pericardial or myocardial blushing on angiography, whereas in type 3 a prominent contrast streaming from $a \geq 1 \mathrm{~mm}$ tear is seen. In cavity spilling subtype (type 4 for some authors) contrast flow from the site of perforation into a cardiac chamber or cavity, such as the left ventricle or coronary sinus, can be seen as opposed to into the pericardium or myocardium. Although there are other classifications used, Ellis classification is the most widely accepted [5].

CAPs may occur with the use of guiding catheters, guidewires, oversized balloon/stents, cutting balloons, IVUS catheters, debulking techniques or with balloon rupture [6]. An important proportion of perforations occur with guidewires while crossing the lesion, with distal wire perforation or wire fracture [7]. Physical features of the wire affect the likelihood of CAP. In general, stiffer guides increase the risk of perforation. Likewise, hydrophilic coated wires were found to be related with CAP in some series [8]. However; this may reflect either use of these low-friction hydrophilic coated wires to facilitate passage through more complex lesions or their ease of distal migration [9].

Treatment of CAP includes prolonged balloon inflation, covered stents, reversal of anticoagulation, embolization of the distal vessel and surgery. Management depends on the site and severity of the perforation, hemodynamic status of the patient and equipment of the catheterization laboratory [10]. Echocardiography should be performed as soon as perforation is identified? If pericardial hemorrhage is present or hemodynamic collapse occurs, pericardiocentesis should be performed [11]. Rapid administration of fluids is also of importance. A balloon should immediately be placed and if perforation cannot be sealed, repeated inflations should be made. Distal ischemia being a concern, perfusion balloons can be used without blocking distal blood flow. Reversal of anticoagulation can be achieved with protamine [12]. GPIIb/IIla inhibitors should also be discontinued and platelet transfusions should be used where needed.

Deployment of a covered stent is another therapeutic approach especially when a large tear involves proximal or mid coronary artery. Autologous vein- covered stents had been used successfully in the past [13]. Polytetrafluoroethylene (PTFE) is an inert and biocompatible polymer composed of carbon chains saturated with fluorine. However, due to the high profile and poor flexibility, it is often difficult to deliver them to the target site, especially when the vessel is heavily calcified and tortuous [14]. Pericardium covered stents with higher flexibility is an alternative for the treatment although the experience is limited [15].

In our patient, coronary angiography of the left coronary artery revealed a significant instent restenosis and we decided to perform PCl. After the lesion was easily crossed with a floppy guide wire and dilated with a compliant balloon, we realized that the inflation balloon was not completely expanded. Moreover, contrast injection revealed marked extravasation indicating Ellis classification type 3 perforation. We thought that continued extravasation was possibly due to unexpanded resistant lesion resulting from underexpansion of the covered stent. Therefore another balloon was advanced to fully expand the stent and final angiography revealed no extravasation.

In conclusion, optimal expansion of the covered-stents to completely treat coronary artery perforations by sealing the lesions is quite important.

Conflict of interest: The authors declared no conflict of interest.

\section{References}

1. Ellis SG, Ajluni S, Arnold AZ et al. Increased coronary perforation in the new device era. Incidence, classification, management and outcome. Circulation 1994;90:2725-2730.

2. Gruberg L, Pinnow E, Flood R et al. Incidence, management and outcome of coronary artery perforation during percutaneous coronary intervention. Am J Cardiol 2000;86:680-682.

3. Shimony A, Joseph L, Mottillo S, Eisenberg MJ. Coronary artery perforation during percutaneous coronary intervention: a systematic review and metaanalysis. Can J Cardiol 2011;27:843-850.

4. Doll JA, Nikolsky E, Stone GW et al. Outcomes of patients with coronary artery perforation complicating percutaneous coronary intervention and correlations with the type of adjunctive antithrombotic therapy: pooled analysis from REPLACE-2, ACUITY, and HORIZONS-AMI trials. J Interv Cardiol 2009;22:453.

5. Muller O, Windecker S, Cuisset $\mathrm{T}$ et al. Management of two major complications in the cardiac catherisation laboratory: the no-reflow phenomenon and coronary perforations. Eurointervention 2008;4:181-192. 
6. Maruo T, Yasuda S, Miyazaki S. Delayed appearance of coronary artery perforation following cutting balloon angioplasty. Catheter Cardiovasc Interv 2002;57:529531

7. Witzke CF, Martin-Herrero F, Clarke SC, Pomerantzev $\mathrm{E}$, Palacios IF. The changing pattern of coronary perforation during percutaneous coronary intervention in the new device era. J Invasive Cardiol 2004;16:257301.

8. Kiernan TJ, Yan BP, Ruggiero $\mathrm{N}$ et al. Coronary artery perforations in the contemporary interventional era. J Interv Cardiol 2009;22:350-353.

9. Al-Mukhaini M, Panduranga $P$, Sulaiman K, Riyami AA, Deeb M, Riyami MB. Coronary perforation and covered stents: an update and review. Heart Views 2011;12:63-70.

10. Shimony A, Joseph L, Mottillo S, Eisenberg MJ. Coronary artery perforation during percutaneous coronary intervention: a systematic review and metaanalysis. Can J Cardiol 2011;27:843-850.
11. Nair P, Roguin A. Coronary perforations. Euro Intervention 2006;2:363-370.

12. Briguori C, Di Mario C, De Gregorio J, Sheiban I, Vaghetti M, Colombo A. Administration of protamine after coronary stent deployment. Am Heart J 1999;138:64-68.

13. Caputo RP, Amin N, Marvasti M, Wagner S, Levy C, Giambartolomei A. Successful treatment of a saphenous vein graft perforation with an autologous vein-covered stent. Cathet Cardiovasc Interv 1999;48:382-386.

14. Romaguera R, Waksman R. Covered stents for coronary perforations: is there enough evidence? Catheter Cardiovasc Interv 2011;78:246-253.

15. Jokhi PP, McKenzie DB, O'Kane P. Use of a novel pericardial covered stent to seal an iatrogenic coronary perforation. J Invasive Cardiol 2009;21:187-190. 